\title{
COOPERATIVE READINESS FOR E-LEARNING
}

\author{
Lucia Sri Istiyowati ${ }^{1}$ and Tiolina Evi ${ }^{2}$ \\ ${ }^{1)}$ Faculty of Information Technology, Perbanas Institute, Jakarta, Indonesia \\ ${ }^{2)}$ Faculty of Business and Economic, Perbanas Institute, Jakarta, Indonesia \\ E-mail: lucia.istyowati@perbanas.id, tiolina@perbanas.id
}

\begin{abstract}
Cooperative is basically an economic organization of the people who have the economic capacity, which is in motion is not only concerned with economic motives. In addition to form a company that requires a profit, the cooperative also has a social motive. This is reflected in the principles espoused. Cooperative is an organization that is familial and managed democratically. In this study the chosen type of credit union, a group of people who agree to raise capital by providing loans to members of its own with a decent interest rate and approved. As one of the requirements in order to be able to make loans to members of cooperatives are the members must have attended training organized by the cooperative board. The spread of the location and the bustle complicate members required to attend training. Development of technology and beneficiaries among members provide alternative learning solutions for members. For that we need to know whether members are ready to accept the training system based on information technology. The readiness of members in this case at CU Melati Kopdit Jagakarta landfill checked by sampling techniques. From preliminary research/beginning it seems that members of the CU Melati landfill Jagakarsa ready to accept the program of distance education (elearning) for cooperative education.
\end{abstract}

Keywords: cooperative, credit, satisfaction, members, economy,e-learning

\begin{abstract}
Abstrak
Koperasi pada dasarnya adalah sebuah organisasi ekonomi rakyat yang memiliki kemampuan ekonomi, yang dalam geraknya tidak hanya peduli dengan motif ekonomi. Selain bentuk perusahaan yang membutuhkan keuntungan, koperasi juga memiliki motif sosial. Hal ini tercermin dalam prinsipprinsip yang dianut. Koperasi adalah organisasi yang bersifat kekeluargaan dan dikelola secara demokratis. Dalam penelitian ini dipilih jenis koperasi kredit (credit union), sekelompok orang yang setuju untuk meningkatkan modal dengan memberikan pinjaman kepada anggota sendiri dengan tingkat bunga yang layak dan disetujui. Sebagai salah satu syarat agar anggota dapat melakukan pinjaman pada koperasi adalah anggota tersebut harus telah mengikuti pelatihan yang diselenggarakan oleh pengurus koperasi. Tersebarnya lokasi dan kesibukan menyulitkan anggota untuk mengikuti pelatihan yang disyaratkan. Perkembangan teknologi dan pemanfaatnya di kalangan anggota memberikan alternatif solusi pembelajaran bagi anggota. Untuk itu perlu di ketahui apakah anggota siap untuk menerima sistem pelatihan/pembalajaran berbasis teknologi informasi. Kesiapan anggota dalam hal ini di CU Melati Kopdit Jagakarta TPA diperiksa dengan teknik sampling. Dari penelitian pendahuluan/awal ini nampak bahwa anggota Kopdit CU Melati TPA Jagakarsa siap untuk menerima program pendidikan jarak jauh (e-learning) untuk pendidikan perkoperasian.
\end{abstract}

Kata Kunci: koperasi, kredit, kepuasan, anggota, ekonomi, e-learning

\section{Introduction}

Credit Union (CU) is a cooperative which is a financial service institution that specifically serves the financial and loan services. The definition of a cooperative is an autonomous association of persons who join voluntarily to meet the needs and aspirations of economic, social and cultural development through the same company that owned and democratically controlled [1].

Credit Union is a financial services institu- tion, in addition to other financial institutions such as banks, state companies and other financial private companies. Indeed, including a business cooperative, which has its own characteristics, which is based on the principles of solidarity, mutual aid, which is in accordance with Indonesian culture. However, as a finance institution, this effort would have more or less the same problems with other financial services companies, although there is its own peculiarities, such that the credit union is not just to pursuit the profit, the 
result is not only enjoyed by the company had only, but for the welfare of members.

Many cooperatives were disbanded because of fraud or diversion of management by managers (e.g. money taken away/corrupted by the board). The principles of the cooperative are open and voluntary membership, democratic supervision by members, members participation in economic activity, autonomy and independence, education or training and information, cooperation among cooperatives, and concern for the community [1].

Considering the importance of cooperatives as one of the financial institution in Indonesia and of the welfare of society, the satisfaction of members of the credit union services/credit union needs to be improved, since the suistanbility and the development of a cooperative is depending on participation of the members, in addition to good organization or management.

CU Melati was established in 1990 in Depok, with more than 3000 members in January 2014 and assets of approximately 27 billion rupiah. Members scattered in various places [2] as shown in TABLE 1 which is incorporated in Place of Member (PoM), which amounts to approximately 20 landfills. Work area includes the city of Depok and surrounding areas, as well as remote areas such as in Wonosari, Gunung Kidul, Yogyakarta. With a large enough number of members and scattered in different places, then surely necessary relationship and good communication, excellent service, and other requirements that cooperatives can grow steadily and sustainability CU Melati chosen because the authors are the member of CU Melati.

TABLE 1

AMOUNT OF MEMBER BASED ON LANDFILLS

\begin{tabular}{lll}
\multicolumn{2}{c}{ AMOUNT OF MEMBER BASED ON LANDFILLS } \\
\hline Landfill & City & Member \\
\hline Jati Asih & Bekasi & 85 \\
Marsudirini & Bogor & 57 \\
Matahari & Bogor & 638 \\
Mawar & Bogor & 97 \\
Morisfoun & Bogor & 60 \\
Salon Susan & Bogor & 60 \\
Triguna & Bogor & 174 \\
Lestari & Bojong Gede & 19 \\
Maju Bersama & Cicurug & 9 \\
Sukmajaya & Cimanggis & 133 \\
Benji & Depok & 510 \\
Cipanas & Depok & 85 \\
Kartini & Depok & 46 \\
Pancoran Mas & Depok & 442 \\
Gunung Kidul & Gunung Kidul & 312 \\
Jagakarsa & Jakarta Selatan & 253 \\
Manunggal Roso & Sukoharjo & 42 \\
\hline Source RAT XIII Kopdit CU Melati, January 2014
\end{tabular}

Cooperative development was seen in the increasing number of members with a diversity of backgrounds of members, income, education or profession. With the development and diversity of member service satisfaction increasingly more difficult to achieve and required a wide range of services to achieve it.

One of the requirements for $\mathrm{CU}$ member is to follow the basic education of the members of the cooperative to be followed to obtain better facilities as a member of the cooperative. Basic education conducted during the two (2) days (Saturday and Sunday) at the beginning of a member, and become one of the prime conditions for obtaining loans. Not all members have the time to follow the education and this can sometimes be a barrier for members and prospective members of the cooperative to be active in the cooperative. To overcome this, we need a solution that can bridge the members and the cooperative so that all members can meet the requirements to obtain maximum service from the cooperative. Information technology as an enabler, very strongly influence people's lives in various fields. Services are supported by technology can improve customer satisfaction or stakeholders.

The number of Internet users grew signifycantly to $22 \%$ from 62 million in 2012 to 74.57 million in 2013. According to some researches, MarkPlus Insight figures the number of Internet users in Indonesia will penetrate to 100 million in 2015. Respondents in the survey were 15-64 years old who regularly access the internet at least 3 hours a day, either through a smartphone, personal computer, laptop, netbook or tablet PC [3]. While social media, especially Facebook user in 2013 reached 50 million and is expected to be 70.6 million more in 2015[4].

This study aimed to find out about: 1) Readiness of CU members with e-learning, 2) Knowledge of cooperative CU members on ICT (Information and Communication Technology) with e-learning. 3) Effect of readiness of members and members' knowledge about ICT with elearning.

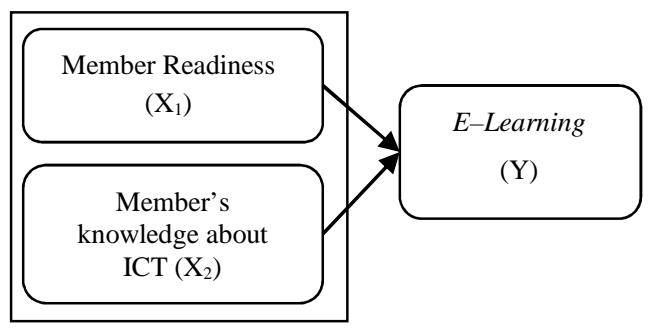

Fig 1. Reasearch Framework 


\section{Research Method}

The research is a quantitative research that aims to find out about:

1) Readiness of CU Melati Jagakarsa members towards e-learning,

2) Knowledge of cooperative members CU Melati Jagakarsa on ICT towards e-learning, and

3) Effect of member readiness and members' knowledge about ICT towards e-learning.

The hypothesis is as follows:

- Ho : There is no significant difference between the readi-nesses of member $(\mathrm{X} 1)$ with e-learning (Y).

- Ho : There is no significant difference between the ICT knowledge of members (X2) with distance educa-tion (Y).

- Ho : There is no significant difference between the readi-ness of member (X1) and ICT knowledge of members (X2) with e-learning (Y).

- H1 : There is a significant relationship between the readi-nesses of member (X1) with e-learning (Y).

- H2 : There is a significant relationship between the ICT knowledge of the members (X2) with e-learning (Y).

- Ha : There is a significant relationship between the readi-ness of member (X1) and ICT knowledge of members (X2) with e-learning $(\mathrm{Y})$.

\section{Cooperative}

The cooperative has the purpose to promote the welfare of members in particular and society in general as well as help build national economic order in order to realize an advanced society, equitable and prosperous based on Pancasila and the 1945 Constitution so cooperative basically did not get any benefit, but members who receive benefits.

The role of cooperatives in the economic community of which is to increase incomes, create jobs, improve living standards and to spread income. Cooperative also has a role in the social sphere by spreading the spirit of voluntary, working together to build a more humane social order, a sense of brotherhood, kinship, also democratic and peaceful society.

Cooperatives also have some kinds of cooperative forms of production and consumption and also credit cooperative. This study focuses on the Credit Union which aims to provide services to members by providing cheap and easy credit. The members agreed to raise capital together to lend among themselves with reasonable interest for a good purpose.

Credit unions intend to operate a non-profit business. In fact, the capital gains and profits of the members are the precise target to be achieved by all the credit unions. However, credit unions are not established merely to benefit the shareholders but also used for the purpose of democratic, social awareness and human development. Development and activities of the credit cooperative movement in Indonesia has been driven by the principles of operation of credit cooperatives (Mission Statement) that is internationally recognized and mission statement developed by the credit cooperative movement in Indonesia.

Credit cooperative services aimed at improving both the economic and social welfare of its members. If there are profits left over from the credit cooperative activities, net of reserve funds and pay dividends is limited on own capital as applicable, then the rest is the right of all members in that no member benefit more while the other members there are losers. The excess was distributed to members in the form of interest or earnings according to the number of transactions they do with credit unions, or it could also be used to increase or hold the additional services needed members.

Relationships between members in the credit union is the relationship between members of a whole, certain parts or target groups within the members, including new members, young people, senior members, members by geographic area (villages or cities) or members who are not active within the credit cooperative. Cooperative Management shall have the authority to make decisions and show leadership that maintained an effective membership. Members also have the assumption that the credit union is a cooperative that runs a strong credit, able to survive and will serve their needs in the future. Therefore the satisfaction of members of credit unions are all concerned in this.

Board undertakes the authority in whether or not a credit union providing cheap and easy credit to members. Then the board must establish and update the goals and policies to guide the development of members, to approve programs and budgets, and to assess the effectiveness of the relationship of members or program development. Member satisfactions have a close relationship with quality. Quality gives an impetus to the members to establish strong ties with the credit union. In the long term bond, it allows credit unions to carefully understand the expectations and needs of their members.

Thus, the cooperative can increase member satisfaction by providing a nice members experience. In turn, the satisfaction of cooperative members can create loyalty to their cooperative mem- 
berships that provides a satisfactory quality. How to achieve member satisfaction, namely: participation of members to be part of all plans and programs concerning members; based on the needs of members, members must regularly obtain the information about credit unions, and cooperative management must communicate effecttively with members, including the development planning members as part of the regular budget process.

In a cooperative organization, the participation of members becomes very important because basically members in cooperative have both roll i.e. as an owner and as a customer of the cooperative. This means the dependency on the participation of members of the cooperative is very high because as owners, members should support the availability of facilities (material and non-material) for the implementation of cooperative organizations and businesses, while as customers, members should take advantage of the potential of cooperative efforts and services. Therefore, the participation of members in the organization and management of the cooperative effort is absolutely necessary.

Although the cooperative has provided economic services for the members, if members do not/do less participation in the cooperative activities, then the service becomes less meaningful. Ropke in [5] explains that the existence of cooperatives as self-help organizations greatly depends on the participation of its members. If the explanation is applied in cooperative, it is not exaggerating to say that cooperative achievement will depend on the level of participation of its members. "Customer satisfaction is a full evaluation of alternatives that have been purchased which is at least equal or exceed customer expectations, while dissatisfaction arise if the results do not meet expectations" [5].

The focus on the quality of the cooperative member satisfaction can be defined simply as a situation where the cooperative credit members feel that the quality of the product exceeds the needs, desires, and their expectations, thus the satisfaction of the members will be high. On the other hand if the members feel that the quality of the product is lower or smaller than the needs, desires, and expectations, then satisfaction of members will get lower. Quality refers to everything that can give satisfaction to members. A product has a high quality if it is produced in accordance with the wishes of members and can be used or utilized properly.

\section{E-learning}

E-Learning can be defined as: "The use of electronic technologies to create learning experiences" [6]. According to Horton, there are some kinds of e-leraning namely [6]:

1) Stand-alone courses: courses taken by a solo learner.

2) Learning games and simulations: Learning by performing simulated activities that requires exploration and leads to discoveries.

3) Mobile learning: Learn-ing from the world while moving.

4) Social Learning: Learning through interaction with a community of experts and fellow learner.

5) Virtual-classroom courses: online classes struc-tured much like a classroom courses, with reading assignments, presentations, discussions via fo-rums and other social media, and home-work.

According to Riyanto et al., E-Learning is a form of applied information technology in education in the form of virtual schools. Elearning can be more effective in stimulating students to explore knowledge [7].

Previous research studies related to the research include: Kataren states that the education of the cooperative credit union is proven to bring benefits and satisfaction for the members of the cooperative in terms of looking at the financial position, the financial risks and to prepare decisions that are based on the actual financial condition [8]. Kataren further states that there is a relationship between formal and non-formal education (cooperative education and entrepreneurship) with the success of the business [8]. Lie states that, "Incorporating digital literacy in education involves methodology and design. As part of the methodology, tools such as Edmodo work effecttively as a bridge to cross over the digital divide and reach out to the digital native students. There is still room for im-provement in the use of technology tools in de-signing and delivering appropriate content to achieve what Prensky calls digital wisdom. Digi-tal literacy should make us not only smarter but also wiser." [9]

\section{Results and Analysis}

\section{Characteristic of Respondents}

The characteristics of a sample of respondents in this study are grouped according to age, gender, education and occupation. To clarify the characteristics of the respondents, the respondent data tables as described in TABLE 2, 3, 4, and 5 are provided:

\section{By Gender}

The overviews of respondent by gender is shown in TABLE 2.

TABLE 2 


\begin{tabular}{|c|c|c|c|c|c|}
\hline \multicolumn{6}{|c|}{ RESPONDENTS BY GENDER } \\
\hline & & Freq. & $\%$ & Valid \% & $\begin{array}{c}\text { Cumulative } \\
\%\end{array}$ \\
\hline & Male & 33 & 37.9 & 37.9 & 37.9 \\
\hline స్ & Female & 54 & 62.1 & 62.1 & 100.0 \\
\hline$>$ & Total & 87 & 100.0 & 100.0 & \\
\hline
\end{tabular}

\section{By Level of Education}

The overview of respondent by level of education is as shown in TABLE 3.

TABLE 3

RESPONDENTS BY LEVEL OF EDUCATIOAN

\begin{tabular}{clcccc}
\hline & Frequency & $\%$ & $\begin{array}{c}\text { Valid } \\
\%\end{array}$ & $\begin{array}{c}\text { Cumulative } \\
\%\end{array}$ \\
\hline & SD & 3 & 3.4 & 3.4 & 3.4 \\
SMP & 1 & 1.1 & 1.1 & 4.6 \\
. & SMA & 25 & 28.7 & 28.7 & 33.3 \\
$>$ & S1 & 26 & 29.9 & 29.9 & 63.2 \\
& S2 & 29 & 33.3 & 33.3 & 96.6 \\
& $>$ S2 & 3 & 3.4 & 3.4 & 100.0 \\
Total & 87 & 100.0 & 100.0 & \\
\hline
\end{tabular}

By Ages

Overviews of respondent by Ages is as shown in TABLE 4.

TABLE 4

RESPONDENTS BY AGES

\begin{tabular}{cccccc}
\hline & & Frequency & $\%$ & Valid \% & $\begin{array}{c}\text { Cumulative } \\
\%\end{array}$ \\
\hline & $20-30$ & 13 & 14.9 & 14.9 & 14.9 \\
$: \overrightarrow{0}$ & $31-40$ & 12 & 13.8 & 13.8 & 28.7 \\
$>$ & $>40$ & 62 & 71.3 & 71.3 & 100.0 \\
& Total & 87 & 100.0 & 100.0 & \\
\hline
\end{tabular}

\section{By Occupation}

Overviews of respondent by occupation is shown in TABLE 5.

TABLE 5

RESPONDENTS BY OCCUPATION

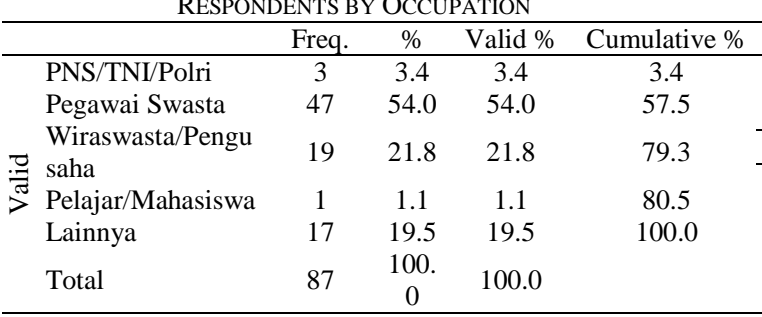

\section{Instruments Test}

The instruments that are used in this research are as follow.

\section{Validity Test}

Validity test used to measure the validity of the questionnaire. A questionnaire is considered valid if the statements in the questionnaire could reveal something that can be measured by the questionnaires. The validity of an item can be seen in the results statement SPSS output table item-total statistics. A variable is said to be valid when the r-count value which is the value of Correlated Item Total Correlation of r-table. Rvalue table can be obtained by df (degree of freedom) $=\mathrm{nk}$, where $\mathrm{n}$ is the number of respondents and $\mathrm{k}$ is the number of grains in a variable declaration. Alpha used in this study was $5 \%$.

TABLE 6

MEMBER READINESS TEST VALIDITY

\begin{tabular}{cccc}
\multicolumn{4}{c}{ MEMBER READINESS TEST VALIDITY } \\
\hline Item & $\mathrm{r}_{\text {count }}$ & $\mathrm{r}_{\text {table }}$ & Information \\
& & & \\
\hline $\mathrm{X} 1 \_1$ & 0.743 & 0.178 & Valid \\
$\mathrm{X} 1 \_2$ & 0.788 & 0.178 & Valid \\
$\mathrm{X} 1 \_3$ & 0.768 & 0.178 & Valid \\
$\mathrm{X} 1 \_4$ & 0,879 & 0.178 & Valid \\
\hline Source:
\end{tabular}

Source: Data processed in 2014

Based on the validity of the test results table readiness of members of the above, it is known that the entire item questions used in this study is valid, as indicated by the value of each item question has a value of Pearson Product Moment $\left(r_{\text {count }}\right)$ positive and greater than the value of $r_{\text {table. }}$

TABLE 7

MEMBERs KNOWLEDGE TEST RESUlts VALIDITY ABOUT ICT

\begin{tabular}{llll}
\hline Item & $\mathbf{r}_{\text {count }}$ & $\mathbf{r}_{\text {table }}$ & Information \\
\hline X2_1 & 0.803 & 0.178 & Valid \\
X2_2 & 0.783 & 0.178 & Valid \\
X3_3 & 0.760 & 0.178 & Valid \\
X4_4 & 0.507 & 0.178 & Valid \\
X5_5 & 0.741 & 0.178 & Valid \\
\hline
\end{tabular}

Source: Data processed in 2014

Based on the validity of the test results table members' knowledge about ICT, it is known that the entire item questions used in this study is valid, as indicated by the value of each item question has a value of Pearson Product Moment $\left(r_{\text {count }}\right)$ positive and greater than the value of $r_{\text {table. }}$

TABLE 8

VALIDITY OF TEST RESULTS DISTANCE EDUCATION (ELEARNING)

\begin{tabular}{cccc}
\multicolumn{4}{c}{ LEARNING) } \\
\hline Item & $\mathrm{r}_{\text {count }}$ & $\mathrm{r}_{\text {table }}$ & Information \\
\hline Y_1 & 0.694 & 0.178 & Valid \\
Y_2 & 0.752 & 0.178 & Valid \\
Y_3 & 0,841 & 0.178 & Valid \\
Y_4 & 0.757 & 0.178 & Valid \\
Y_5 & 0.706 & 0.178 & Valid \\
Y_6 & 0.738 & 0.178 & Valid \\
Y_7 & 0.701 & 0.178 & Valid \\
\hline
\end{tabular}

Source: Data processed in 2014

Based on the validity of the test results table distance education (e-Learning), it is known that the entire item questions used in this study is valid, as indicated by the value of each item question has a value of Pearson Product Mo-ment $\left(r_{\text {count }}\right)$ positive and greater than the value of $r_{\text {table. }}$ 


\section{Reliability Test}

Reliability indicates the consistency and stability of the score of a measuring instrument. A questionnaire can be said realiable or reliable if someone answers on the statement is consistent or fixed from time to time. Reliability test is intended to determine the consistency of measurement variables. Reliable measurement instrument shows that the questionnaires are trusted and can produce reliable data as well. The reliability of a variable can be good if it has the value of Cronbach's Alpha $>0.60$.

TABLE 9

\begin{tabular}{lll}
\multicolumn{3}{c}{ RELIABILITY TEST RESULTS } \\
\hline Variables & $\begin{array}{l}\text { Cronbach } \\
\text { Alpha }\end{array}$ & Information \\
& 0.802 & Reliable \\
Members readiness (X1) & 0.767 & Reliable \\
$\begin{array}{l}\text { Member knowledge about ICT } \\
\text { (X2) }\end{array}$ & & \\
$\begin{array}{l}\text { Distance Education/e-Learning } \\
(Y)\end{array}$ & 0.861 & Reliable
\end{tabular}

(Y)

Source: Data processed in 2014

Based on testing in table 4 reliability test is known that all the variables have Cronbach Alpha greater than 0.60 , so it can be concluded that the overall variable in this study is reliable.

\section{Classical Assumption Test}

The classical assumption tests that are used in this research are as follow.

\section{Normality Test}

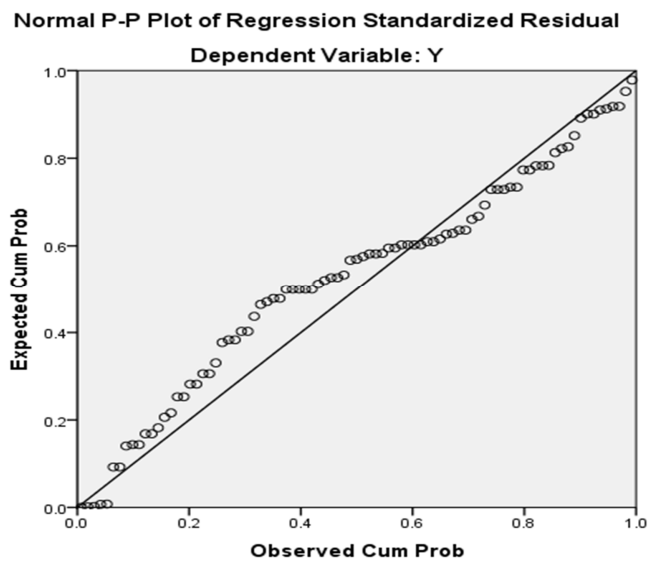

Fig 2. Normal PP Plot

Normality test is to see if the residual value is normally distributed or not. A good regression model is to have a residual value that is normally distributed. So normality test is not performed on each variable but the residual value.

Detection of normality of the data can be seen from the spread of points on the diagonal axis of the graph. In the graph shows the data spread around the diagonal line and follow the direction of the diagonal line. Thus, the model in this study meets the test for normality.

\section{Test Multicollinearity}

Multicollinearity test aimed to see whether or not a high correlation between independent variables in a multiple regression model. If there is a high correlation between the independent variables, the relationship between the independent variable on the dependent variable will be disturbed.

TABLE 10

Test RESUlts MultiCOLLINEARITy COEFFICIENTS ${ }^{\text {A }}$

\begin{tabular}{cccc}
\hline Model & $\begin{array}{c}\text { Collinearity } \\
\text { Statistics } \\
\text { Tolerance }\end{array}$ & $\begin{array}{c}\text { Collinearity } \\
\text { Statistics } \\
\text { VIF }\end{array}$ \\
\hline \multirow{2}{*}{1} & $\begin{array}{c}\text { (Constant) } \\
\text { X1 }\end{array}$ & .264 & \\
& $\mathrm{X} 2$ & .264 & 3783 \\
\hline
\end{tabular}

Source: Output data from IBM SPSS Statistics 21.0 2014

From the analysis, obtained two independent variables (independent) in this study are its VIF under 10 and his tolerance close to 1 . This means that there is no multicollinearity between the independent variables.

\section{Test Autocorrelation}

Autocorrelation is a state in which the correlation of residuals for the observation of one with the other observations arranged in time series. A good regression model requires the absence of autocorrelation problem.

TABLE 11

Autocorrelation TeSt RESUlts Model SumMARy

\begin{tabular}{cccccc}
\multicolumn{5}{c}{ AUTOCORRELATION TEST RESULTS MODEL SUMMARY } \\
\hline Model & $\mathrm{R}$ & $\begin{array}{c}\mathrm{R} \\
\text { Square }\end{array}$ & $\begin{array}{c}\text { Adjusted } \\
\text { R Square }\end{array}$ & $\begin{array}{c}\text { Std. Error } \\
\text { of the } \\
\text { Estimate }\end{array}$ & $\begin{array}{c}\text { Durbin- } \\
\text { Watson }\end{array}$ \\
\hline 1 & $\begin{array}{c}.860 \\
\mathrm{~A}\end{array}$ & .740 & .733 & 2.390 & 1,375 \\
\hline \multicolumn{4}{l}{ Source: Data output IBM SPSS Statistics 21.0 2014 }
\end{tabular}

How to test the autocorrelation can be done with the test Durbin Watson. Multiple linear regression equation free from autocorrelation if the value of the Durbin Watson count on SPSS output located in the area $d$ (no autocorrelation) or the value calculated Durbin Watson honing 2. The output value of the results of SPSS by 1,375 , based on the output of the above it can be seen that there is no auto-correlation.

\section{Heterokedastity Test}

Heteroscedasticity test is to see whether there is inequality and residual variance one observation to another. This regression model that meets the requirements is where there is equality of variance of the residuals of the observations to other observations remains or called homoske- 


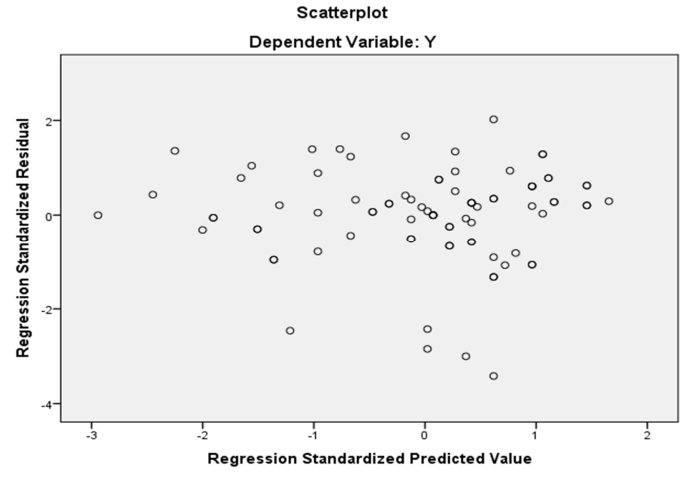

Fig. 3. Regression Model. Source: output data from IBM SPSS Statistics 21.02014

dastisitas.

From the Fig. 3, it is shown that there is no clear pattern, namely point spread, thus there is no heteroskedastisitas problem indicated.

\section{Multiple Regression Test}

Multiple regressions test is used to determine the direction and magnitude of the influence of the independent variables of more than one member and to measure the readiness and knowledge of the ICT (information and communication technology) members on the dependent variable in the distance education (e-Learning).

TABLE 12

RESUltS OF MULTIPLE LINEAR REGRESSION ANALYSIS COEFFICIENTS $^{\text {A }}$

\begin{tabular}{|c|c|c|c|c|c|c|}
\hline \multirow{2}{*}{\multicolumn{2}{|c|}{ Model }} & \multicolumn{2}{|c|}{$\begin{array}{l}\text { Unstandardized } \\
\text { Coefficients }\end{array}$} & \multirow{2}{*}{$\begin{array}{l}\text { Standa } \\
\text { rdized } \\
\text { Coeffi } \\
\text { cients } \\
\text { Beta }\end{array}$} & \multirow[t]{2}{*}{$\mathrm{t}$} & \multirow[t]{2}{*}{ Sig. } \\
\hline & & B & $\begin{array}{l}\text { Std. } \\
\text { Error }\end{array}$ & & & \\
\hline \multirow{3}{*}{1} & (Const.) & 2,831 & 1,683 & & 1682 & .096 \\
\hline & $\mathrm{X} 1$ & .586 & .200 & .317 & 2928 & .004 \\
\hline & $\mathrm{X} 2$ & .790 & .149 & .572 & 5285 & .000 \\
\hline
\end{tabular}

Based on data analysis using IBM SPSS Statistics 21.0 program, the regression equation is as shown in equation (1) as follows.

$Y=2,831+0.790 X 0.586 X 1+2+e$

\section{F Test (Unison Test)}

$\mathrm{F}$ test is conducted to test whether all independent variables simultaneously affect the dependent variable with a confidence level of $95 \%$ (alpha 5\%) or not. The null hypothesis (Ho) is reached by setting all the parameters in the model to zero, hence Ho: $\beta 1=\beta 2=0$, which means there is no influence of independent variables on the dependent variable. Whereas in the alternative hypothesis (Ha) all parameters are not set to zero, thus Ha: $\beta 1 \neq \beta 2=0$ which means that there is influences of independent variables on the dependent variables simultaneously. Thus the $\mathrm{p}$-value in $\mathrm{Ho}>0.05$, p-value of $\mathrm{Ha}<0.05$.

TABLE 13

TEST RESULTS TEST F ANOVA

\begin{tabular}{llcccccc}
\hline \multirow{2}{*}{ Model } & $\begin{array}{l}\text { Sum of } \\
\text { Squares }\end{array}$ & Df & \multicolumn{2}{c}{ Mean Square } & F & \multicolumn{2}{c}{ Sig. } \\
\hline \multirow{4}{*}{1} & Regression & 1362.083 & 2 & 681 & 119 & .000 \\
& & & & 042 & 249 & B \\
& Residual & 479733 & 84 & 5711 & & \\
& Total & 1841.816 & 86 & & & \\
\hline
\end{tabular}

Source: Data output IBM SPSS Statistics 21.0 2014

Based on the above analysis, it can be seen that there is influence of independent variables on the dependent variable. This can be seen in the Sig. labeled column, whose value is below 0,05 or more precisely 0,00 , so $\mathrm{Ha}$ is received while $\mathrm{Ho}$ is rejected.

Based on the test results $\mathrm{F}$ (simultaneously), it can be seen that there is influence of the independent variables (the readiness of members and the ICT knowledge of members) on the dependent variable (distance education). It can be seen in the sig. column, where the value is below 0,05 or more precisely 0,000 , so $\mathrm{Ha}$ is received, while Ho is rejected, can be seen in TABLE 13 .

\section{T test (Partial Test)}

$\mathrm{T}$ test is intended to determine whether partially independent variables affect the dependent variable, with the following conditions: Ho: $\beta 1=0$, which means there is no influence between independent variables with the dependent variable. Ha: $\beta \neq 0$, which means that there is influence between independent variables and the dependent variable individually. Thus the $\mathrm{p}$-value in $\mathrm{Ho}>0.05$, $\mathrm{p}$-value of $\mathrm{Ha}<0.05$.

Based on the data analysis using IBM SPSS Statistics 21.0, to produce sig value of 0.004 the readiness of member needs $t$ value of 2.928 . Meanwhile the value of the distribution table with an error rate of $5 \%$, and $\mathrm{df}$ (nk) is equal to 1,988 . Hence $t(2.928)>t_{\text {table }}(1.988)$. This means the rea-diness of member variables $\mathrm{X}_{1}$ has a positive influence. It is also strengthened by the significant value of $0,004(<0,050)$ which means variable readiness member $X_{1}$ has positive and significant impact on distance education $\mathrm{Y}$.

On the other hand, the knowledge of members of the ICT (Information and Communication Technology) produces sig value of 0.000 and $t$ value for this variable is 5.285. Meanwhile the value of the distribution table with an error rate of $5 \%$, and $\mathrm{df}(\mathrm{nk})$ is equal to 1,988 . Hence $\mathrm{t}(5.285)>$ $t_{\text {table }}$ (1.988). This means that the variable knowledge of the members of the ICT $\mathrm{X}_{2}$ has a positive influence. It is also strengthened by the significant 
value of $0,000(<0,050)$ means that the variable knowledge of the members of the ICT $X_{2}$ has positive and significant impact on distance education Y.

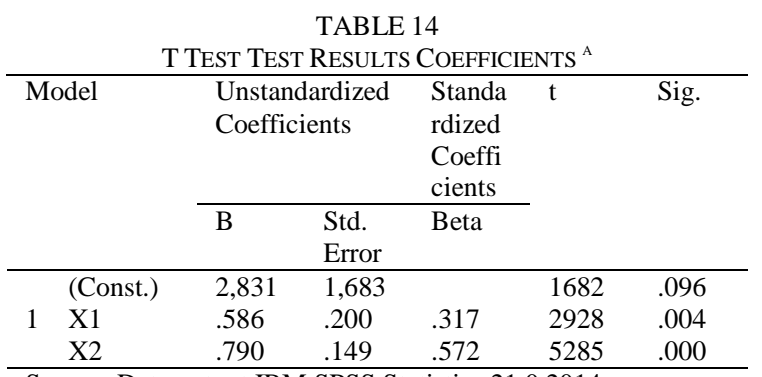

Source: Data output IBM SPSS Statistics 21.0 2014

The coefficient of determination $\left(R^{2}\right)$

In multiple linear models, the influence of the independent variables on the dependent variables is observed by looking for the total size of the coefficient of determination $R^{2}$. If $R^{2}$ is closer to 1 , it can be said that it is the strongest model to explain the relationship of independent variables on dependent variables. Conversely, the closer $\mathrm{R}^{2}$ to zero, the weaker the influence of independent variables on the dependent variable is.

TABLE 15

RESUlTS COEFFICIENT OF DETERMINATION MODEL SUMMARY

\begin{tabular}{cccccc}
\multicolumn{6}{c}{ SUMMARY $^{\mathbf{B}}$} \\
\hline $\begin{array}{c}\text { Mo- } \\
\text { del }\end{array}$ & $\mathrm{R}$ & $\mathrm{R}^{2}$ & $\begin{array}{c}\text { Adjusted } \\
\mathrm{R}^{2}\end{array}$ & $\begin{array}{c}\text { Std. Error } \\
\text { of the } \\
\text { Estimate }\end{array}$ & $\begin{array}{c}\text { Durbin } \\
- \\
\text { Watson }\end{array}$ \\
\hline 1 & $.860^{\mathrm{A}}$ & .740 & .733 & 2.390 & 1,375 \\
\hline
\end{tabular}

Source: Data output IBM SPSS Statistics 21.0 2014

Based on the analysis described in TABLE 15 , it can be seen that the value of the adjusted $R^{2}$ is 0.740 or $74.0 \%$. It indicates that $74.0 \%$ which is the dependent variable of distance education can be explained by two independent variables, namely the readiness of members and the knowledge of members about ICT.

\section{Correlation}

Correlation test does not distinguish the types of variables (no dependent or independent variable). The relationship is expressed in terms of cor-relation coefficient. Correlation test aims to examine the relationship between two variables that does not show the functional relationship. The correlation coefficient has a value between -1 and +1 . The nature of the correlation coefficient is plus (+) and minus (-).

Based on the results defined in TABLE 16, the readiness of members has a very strong correlation of 0.858 and ICT knowledge of members. The value $\mathrm{p}$-value indicates the results on the sig. (2-tailed) column which is $0.000(<0.05)$. It means that there is correlation between the readi- ness of members and ICT knowledge of members

TABLE 16

CORRELATION ANALYSIS CORRELATIONS

\begin{tabular}{llrrr}
\multicolumn{5}{c}{ CORRELATION ANALYSIS CORRELATIONS } \\
\hline & X1 & X2 & \multicolumn{1}{c}{ Y } \\
\hline X1 & Pearson Correlation & 1 & $.858^{* *}$ & $.808^{* *}$ \\
& Sig. (2-tailed) & & .000 & .000 \\
& N & 87 & 87 & 87 \\
X2 & Pearson Correlation & $.858^{* *}$ & 1 & $.844^{* *}$ \\
& Sig. (2-tailed) & .000 & & .000 \\
& N & 87 & 87 & 87 \\
Y & Pearson Correlation & $.808^{* *}$ & $.844^{* *}$ & 1 \\
& Sig. (2-tailed) & .000 & .000 & \\
& N & 87 & 87 & 87 \\
\hline Source: Data output IBM SPSS Statistics 21.02014
\end{tabular}

Source: Data output IBM SPSS Statistics 21.02014

The readiness of members variable has a very strong correlation and distance education (eLearning) of 0.808 . The p-value indicates the results on the sig. (2-tailed) column of 0.000 (< $0.05)$. It means that there is correlation between the readiness of members and distance education.

The variable of ICT knowledge of members has a very strong correlation value of 0.844 with distance education. The $\mathrm{p}$-value indicates the results on the sig. (2-tailed) column of 0.000 (< $0.05)$. It means that there is correlation between ICT knowledge of members with distance education.

\section{Conclusion}

Research results of the readiness of members in the CU Melati Jagakarsa showed that the members are ready to carry out distance education or E-Learning in particular regarding the cooperative education. Members agree and believe that CU do and facilitate distance education.

From the result it can be concluded that the variable of ICT knowledge of the members has a positive influence. It means that the variable knowledge of the members of the ICT has positive and significant impact on distance education in CU Melati Jagakarsa. It is very supportive when cooperatives organize distance education. Educational materials related to the cooperative concept can be provided on the cooperatives page. The CU member has a sufficient ICT knowledge and has a habit of using internet.

The variable of member readiness with the variable of ICT knowledge of members of together have a significant and positive effect on the variable distance education in CU Melati Jagakarsa.

From the preliminary research it seems that members of the CU Melati Jagakarsa are ready to receive distance education programs for cooperative education. The educational method of e-learning is consistent and compatible with andraogi education, namely education for adults where 
most of the members are adults who already have a job or their own livelihood. They usually prefer to learn independently and at leisure time they have.

\section{References}

[1] ACCU, "ACCESS: Auditor's Manual, dalam Credit Union Solution Series Terj Bangkok." Bangkok, 2009.

[2] "RAT XXIII," CU Melati, Depok, Jan. 2014.

[3] T. text provides general information S. assumes no liability for the information given being complete or correct $\mathrm{D}$. to varying update cycles and S. C. D. M. up-to-D. D. T. R. in the Text, "Topic: Internet usage in Indonesia," www.statista.com. [Online]. Available: http://www.statista.com/topics/2431/ internet-usage-in-indonesia/. [Accessed: 18Sep-2015].

[4] "Indonesia: number of Facebook users 20122018 | Statistic," Statista. [Online]. Available: http://www.statista.com/statistics/304829/nu mber-of-facebook-users-in-indonesia/. [Accessed: 21-Sep-2015].

[5] H. Syahrudin, "Hubungan antara Manfaat Koperasi dengan Partisipasi Anggota," Universitas Padjajaran, Bandung, 2003.

[6] W. Horton, E-learning by Design, Second. Pfiffer, 2012.

[7] D. E. Riyanto, E. A. Sarwoko, and Kushartantya, "E-learning sebagai model proses pembelajaran berbasis Teknologi Informasi," presented at the Semiinar Nasionatl SPMIPA, 2006.

[8] N. Kataren, "Faktor-Faktor yang Mempengaruhi Keberhasilan Koperasi Credit Union dalam Pemberdayaan Masyarakat (Studi Kasus: Koperasi Credit Union Partisipasi Sukamakmur Kecamatan Sibolangit, Kabupaten Deli Serdang)," J. Harmoni Sos., vol. I, no. 3, Mei 2007.

[9] Anita Lie, "Social Media In A Content Course For The Digital Natives," TEFLIN Journal, p. 48, 2013. 